\title{
ФОРМУВАННЯ ФРАКЦІЙНОГО СКЛАДУ ТА ПОСІВНИХ ЯКОСТЕЙ НАСІННЯ БАТЬКІВСЬКИХ КОМПОНЕНТІВ КУКУРУДЗИ ЗАЛЕЖНО ВІД ГУСТОТИ СТОЯННЯ
}

\author{
B. В. БАГАТЧЕНКО, аспірант* \\ https://orcid.org/0000-0001-7595-5918 \\ В. Л. ЖЕМОЙДА, кандидат сільськогосподарських наук доцент \\ http://orcid.org/0000-0002-4411-1592 \\ P. О. СПРЯЖКА, аспірант* \\ https://orcid.org/0000-0001-7434-084X \\ Національний університет біоресурсів і природокористування України \\ E-mail: volodimirbagatchenko@ukr.net
}

\begin{abstract}
Анотація. Представлені результати досліджень впливу густоти стояння на вихід фракційного складу та посівні якості насіння батьківських компонентів кукурудзи (простих гібридів) Picm CB, Рушник CB, Річка C та (самозапилених ліній) УР 9зС, УР 331 СВ, УР 12 зС, які є батьківськими компонентами гібридів кукурудзи занесених до Державного реєстру сортів рослин України.

Встановлено, що досліджувані батьківські компоненти забезпечили формування різних фракцій та посівних якостей насіння залежно від генетичних особливостей та різної густоти стояння рослин, що дозволило оптимізувати досліджувані агротехнічні прийоми їхнього вирощування.

Оптимальними густотами стояння рослин які дозволяють підвищити вихід насіння найбільш цінних I та II фрракцій кукурудзи та їхніх посівних якостей(маса 1000 насінин, енергія проростання, схожість) відповідно для батьківських компонентів Pіст CB (62,5 \%, 24,5 \%, 287,2 2, 95,9 \%, 98,6 \%) та Рушник CB (65,0 \%, 20,0 \%, 326,2 2, 95,6 \%, 99,0\%) являється-75 тис./га; для Річки C (65,0\%, 20,0\%, 254,72, 95,4\%, 97,2\%) йУР 331 СВ (61,0\%, 23,0\%, 266,6 г, 96,0\%, 99,0\%) - 95 mис./га та для УР 9 зС (63,7\%, 21,3 \%, 228,5 г, $94,4 \%, 98,8 \%)$ й УР 12 зС (63,7\%, 21,3\%, 316,9 2, 96,6\%, 99,5\%)-85 muc./2a.
\end{abstract}

Ключові слова: кукурудза, батьківські компоненти, самозапилені лінії, густота стояння рослин, фракційний склад, посівна придатність

\section{Актуальність.}

Батьківські компоненти кукурудзи (прості гібриди та лініі) мають певні морфологічні та біологічні особливості. Потенційну продуктивність для кожного біотипу можливо отримати за умов створення сприятливих для росту та розвит-

*Науковий керівник - В. Л. Жемойда 
ку рослин умов, а саме застосовуючи різні прийоми агротехніки вирощування та використовуючи природно - кліматичні ресурси зони вирощування.

Одним 3 основних шляхів підвищення врожайності і зниження собівартості насіння є підвищення густоти стояння рослин. Однак, водночас, необхідно пам'ятати, що за надмірного загущення рослин погіршуються елементи структури врожаю та якість зерна. Тому, вивчення реакції батьківських компонентів кукурудзи на загущення $є$ дуже актуальним завданням.

\section{Аналіз останніх досліджень ма публікацій.}

Оптимальна густота рослин $є$ одним із найважливіших чинників для одержання високих урожаїв кукурудзи (Красновський С. А., Жемойда В. Л., 2010; Каленська С. М., Таран В. Г., 2018). Існує різноманітність реакцій генотипів кукурудзи на загущення та можливість відбору форм, що не знижують врожайність зі збільшенням густоти стояння до певної межі, тому дослідні установи випробовували окремі лінії та гібриди за різної густоти (Панькін В. C., Павлюк O.O., 2005; Allard R. W., 1996). Кукурудза, на відміну від багатьох інших культур, більш чутлива до зміни густоти стояння (Хромяк В.M., 1986). Оптимальна кількість продуктивних рослин на гектар та їхнє рівномірне розподілення в рядках є одним із чинників, які визначають рівень врожайності кукурудзи (Абельмасов О. В., Бебех А. В., 2018), створюючи сприятливі умови для фотосинтезу, кращого використання родючості грунтів, вологи та добрив ( Kemanian A. R., Stöckle C. O., 2007).

Необхідно зазначити, що різні гібриди спроможні давати максимальний урожай за різної густоти стояння рослин, оскільки розміри листового апарату і тривалості його роботи значною мірою обумовлюються генетично закріпленими можливостями гібридів (Лещук Н. В. та ін., 2013).

Важливе значення має також фракція насіння і глибина його загортання. Дослідженнями, проведеними на дослідному полі Луганського національного аграрного університету Капустіним C. I., встановлено, що насіння простих гібридів крупної фракції мало польову схожість $98 \%$, тоді як середньої в межах 66-75 \%, і відповідно до глибини загортання 9-12 см і 6-12 cм. Вони також зазначають, що в посушливих умовах за сівби насіння крупної фракції за глибини загортання $9 \mathrm{~cm}$ зерно мало нижчу збиральну вологість, рослини були вищими та мали довші качани ( Капустін С. I. та ін., 2009).

Густота рослин кукурудзи сильно впливає на вологозабезпеченість. Рослини у найбільш загущених посівах використовують запаси доступної вологи в метровому шарі грунту на розвиток вегетативних органів, в основному в першій половині вегетаційного періоду. Кризовий, щодо вологозабезпеченості період у кукурудзи починається після утворення 12-13 листків у середньоранніх і середньостиглих та 14-15-у середньопізніх і пізньостиглих гібридів. На час утворення качанів вологозабезпеченість рослин різко погіршується, що у разі загущення посівів призводить до гальмування ростових процесів, зниження інтенсивності фотосинтезу і до зниження продуктивності рослин (Teller E. at. al., 1999).

Мета дослідження - установити особливості формування фракційного складу та показників посівних якостей насіння батьківських компонентів кукурудзи за різної густоти стояння рослин в умовах Лісостепу України. 


\section{Матеріали й методи дослідження.}

Експериментальну роботу виконували впродовж 2014-2018 рр. на дослідних полях ТОВ «Агрофірма «Колос»; лабораторні дослідження проводили в «Дослідній лабораторії» ТОВ «Агрофірма «Колос». Погодні умови 2014-2018 pр. були сприятливими для вирощування насіння кукурудзи та проведення досліджень, проте були контрастними за роками. Сумарна кількість опадів за квітень - жовтень становила: у 2014 році - 474,6 мм, 2015 році - 268,2 мм, 2017 році $-226,8$ мм та у 2018 році350,6 мм. Сума ефективних температур становила: у 2014 році $-2170,7^{\circ} \mathrm{C}, 2015$ році $-2011{ }^{\circ} \mathrm{C}, 2017$ році $-2145,3{ }^{\circ} \mathrm{C}$ та у 2018 році $-1957,6{ }^{\circ} \mathrm{C}$.

Площа облікової ділянки 7, 35м2. Повторність дослідів трьох разова. Посів проводили рендомізованим способом.

Матеріалом для досліджень слугували батьківські компоненти: самозапилені лінії (УР 9 зС, УР 331 CB,УР $12{ }_{3}$ ) ) та прості гібриди (Ріст $\mathrm{CB}$, Рушник CB, Річка C).

Варіанти густоти стояння батьківських компонентів: гібриди $(75,85$, 95 тис./га); лінії (85, 95, 105 тис./га).

Польові та лабораторні дослідження проводили відповідно до чинних методик, а саме: «Методики дослідної справи» (Доспехов Б. А., 1989), «Методики проведення експертизи сортів рослин групи зернових, круп'яних та зернобобових на придатність до поширення в Україні» (Ткачик С. О., 2016); «Методика проведення експертизи сортів рослин групи зернових на відмінність, однорідність і стабільність» (Ткачик С. О., 2016).

Визначення фракційності насіння проводили використовуючи лаборатор- ні сита. Насіння ділили на 4 фракції:I фракція - КП (крупні плоскі) ширина понад 8,0 мм, товщина менше ніж 5,5 мм; II фракція - МП (мілкі плоскі) ширина 6,5-8,0 мм, товщина менше ніж 5,0 мм; III фракція - КК (крупні круглі) ширина понад 8,0 мм, товщина понад 5,5 мм; IV фракція - КМ (мілкі круглі) ширина 6,5-8,0 мм, товщина 5,0 мм.

Попередник - пшениця м'яка озимого типу розвитку. Сівбу батьківських компонентів гібридів і самозапильних ліній кукурудзи проводили на глибину 4-6 см ручними сівалками на різну густоту стояння рослин $75,85,95$, 105 тис./га 3 наступним прикочуванням кільчасто-шпоровими котками.

Облік та формування густоти стояння проводили у фазі 3-5 листків окремо за кожною ділянкою.

\section{Результати дослідження та їх обговорення.}

Аналіз показників структури урожаю батьківських компонетів кукурудзи, а саме: довжина початку, діаметр початку, кількість рядів зерен та кількість зерен в ряду є важлими ідентифікаційними ознаками кукурудзи та важливими складовими формування насіннєвої продуктивності та урожайності насіння загалом. Вплив густоти стояння рослин кукурудзи на структуру урожаю батьківських компонентів гібридів кукурудзи приведено в таблиці 1.

Як видно 3 даних таблиці 1. гібрид Ріст CВ сформував типові вирівняні качани довжиною 20,0 см та діаметром 4,7 см за густоти стояння 75 тис./га. 3 підвищенням густоти стояння, довжина качанів і діаметр зменшувалися. За густоти стояння рослин 85 тис./га качани були із найбільшою кількістю рядів 15,2 шт, але кількість зерен у ряду в середньому була нижчою. Ана- 


\section{1. ВПлив густоти стояння на показники структуру урожаю батьківських компонентів кукурудзи (середнє 2014-2018 р.p.)}

\begin{tabular}{|c|c|c|c|c|c|}
\hline \multirow{2}{*}{$\begin{array}{l}\text { № дослі- } \\
\text { ду }\end{array}$} & \multirow{2}{*}{$\begin{array}{l}\text { Густота стояння, } \\
\text { тис./га (фактор Б) }\end{array}$} & \multicolumn{2}{|c|}{ Початок: } & \multirow{2}{*}{$\begin{array}{l}\text { Кількість } \\
\text { рядів, шт }\end{array}$} & \multirow{2}{*}{$\begin{array}{c}\text { Число зерең } \\
\text { в ряду, шт }\end{array}$} \\
\hline & & довжина, см & діаметр, см & & \\
\hline \multicolumn{6}{|c|}{ Ріст СВ (фактор А) } \\
\hline 1 & 75 & 20,0 & 4,7 & 14,8 & 40,4 \\
\hline 2 & 85 & 19,1 & 4,6 & 15,2 & 38,8 \\
\hline 3 & 95 & 19,5 & 4,7 & 16,0 & 38,0 \\
\hline \multicolumn{6}{|c|}{ Рушник СВ (фактор А) } \\
\hline 1 & 75 & 21,0 & 5,0 & 14,4 & 39,8 \\
\hline 2 & 85 & 19,6 & 5,0 & 15,6 & 35,0 \\
\hline 3 & 95 & 17,5 & 4,8 & 14,8 & 34,8 \\
\hline \multicolumn{6}{|c|}{ Річка С (фактор А) } \\
\hline 1 & 75 & 18,1 & 4,7 & 14,4 & 36,2 \\
\hline 2 & 85 & 18,0 & 4,7 & 15,6 & 36,6 \\
\hline 3 & 95 & 19,2 & 4,8 & 14,8 & 37,0 \\
\hline \multicolumn{6}{|c|}{ УР 9зС (фактор А) } \\
\hline 1 & 85 & 15,7 & 3,9 & 14,4 & 31,8 \\
\hline 2 & 95 & 14,9 & 3,8 & 12,8 & 30,8 \\
\hline 3 & 105 & 12,5 & 4,0 & 15,9 & 25,4 \\
\hline \multicolumn{6}{|c|}{ УР 331 СВ (фактор А) } \\
\hline 1 & 85 & 13,1 & 4,2 & 15,2 & 25,0 \\
\hline 2 & 95 & 13,7 & 4,4 & 15,6 & 25,8 \\
\hline 3 & 105 & 12,7 & 4,2 & 15,6 & 25,4 \\
\hline \multicolumn{6}{|c|}{ УР 12 зС (фактор А) } \\
\hline 1 & 85 & 12,7 & 4,5 & 15,6 & 22,4 \\
\hline 2 & 95 & 14,5 & 4,4 & 15,6 & 30,4 \\
\hline 3 & 105 & 13,5 & 4,5 & 15,2 & 26,4 \\
\hline \multicolumn{2}{|r|}{ HIP 05 АБ } & 1,10 & 0,19 & 0,89 & 1,05 \\
\hline \multicolumn{2}{|r|}{ HIP A } & 0,63 & 0,11 & 0,52 & 0,61 \\
\hline \multicolumn{2}{|r|}{ НIP Б } & 0,67 & 0,12 & 0,54 & 0,67 \\
\hline
\end{tabular}

логічна залежність спостерігалася і у гібриду Рушник CB, довжина качана якого склала 21 см за густоти стояння 75 тис./га, $з$ діаметром близько 5 см. Однак, у гібриду Річка С найдовші качани були сформовані за густоти стояння 95 тис./га. Самозапильні лінії УР 12 зС та УР $331 \mathrm{CB}$ сформували качани довжиною 14,5 і 13,7 см відповідно за густоти 95 тис./га. Для самозапильної лінії УР 9 зС оптимальною виявилася густота 85 тис./га, яка забезпечила найкращі показники структури урожаю: довжину початку $-15,7$ см, діаметр - 3,9 см та число зерен в ряду 31,8 шт. 


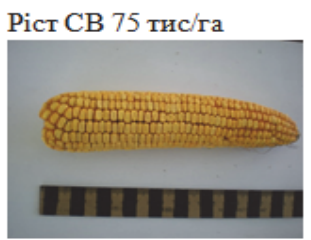

Piст CB 85 тис/га

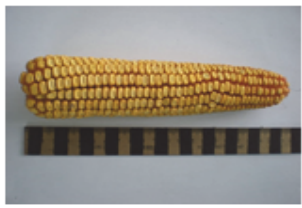

Piст CВ 95 тис/га

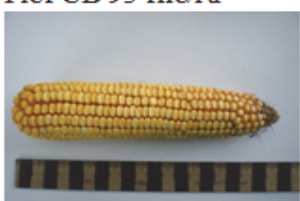

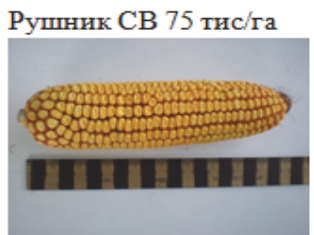

Рушник СВ 85 тис/га

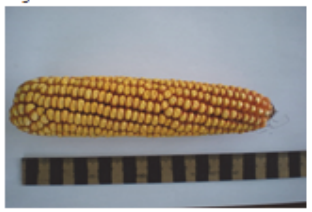

Рушник СВ 95 тис/га

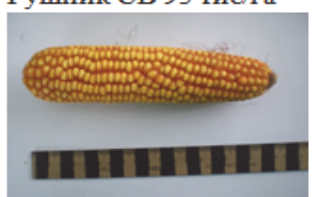

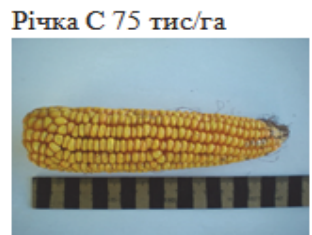

Piчка C 85 тис/га

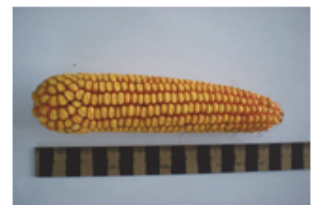

Pічка C 95 тис/га

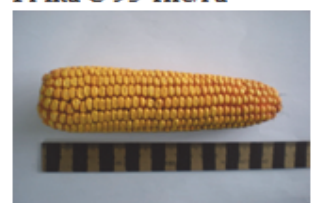

Рис. 1. Початки батьківських компонентів (гібридів) залежно від густоти стояння
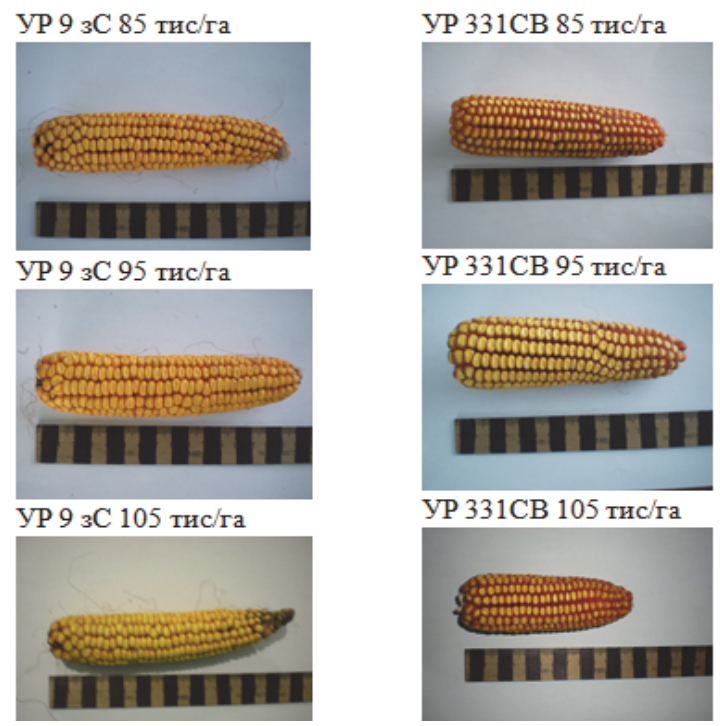

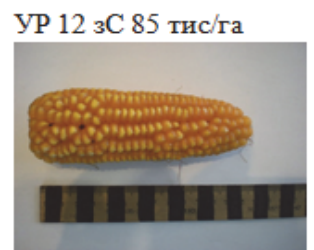

ур 12 зС 95 тис/га

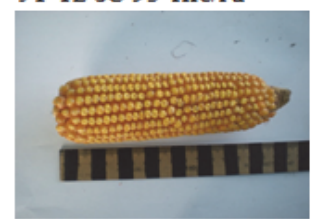

УР 12 зС 105 тис/га

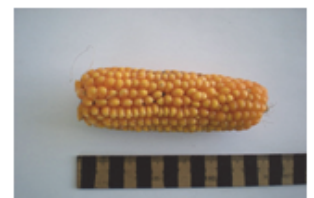

Рис. 2. Початки батьківських компонентів (ліній) залежно від густоти стояння

За результатами аналізу проведених досліджень відмічено (рис. 3), що найвищий вихід кондиційного насіння I фракції був у всіх трьох гібридів Ріст СВ - 62,5 \%, Рушник $\mathrm{CB}-65,0 \%$, Річка $\mathrm{C}-65,0 \%$ за густоти стояння 75 тис./га. Найвищі показники виходу насіння I фракції серед ліній, зокрема УР $3 \mathrm{C}$ - 63,7\%, УР 331 СВ - 65,0 \%, УР 12 3С - 32,0 \% зазначено за густоти посіву 85 тис./га. 


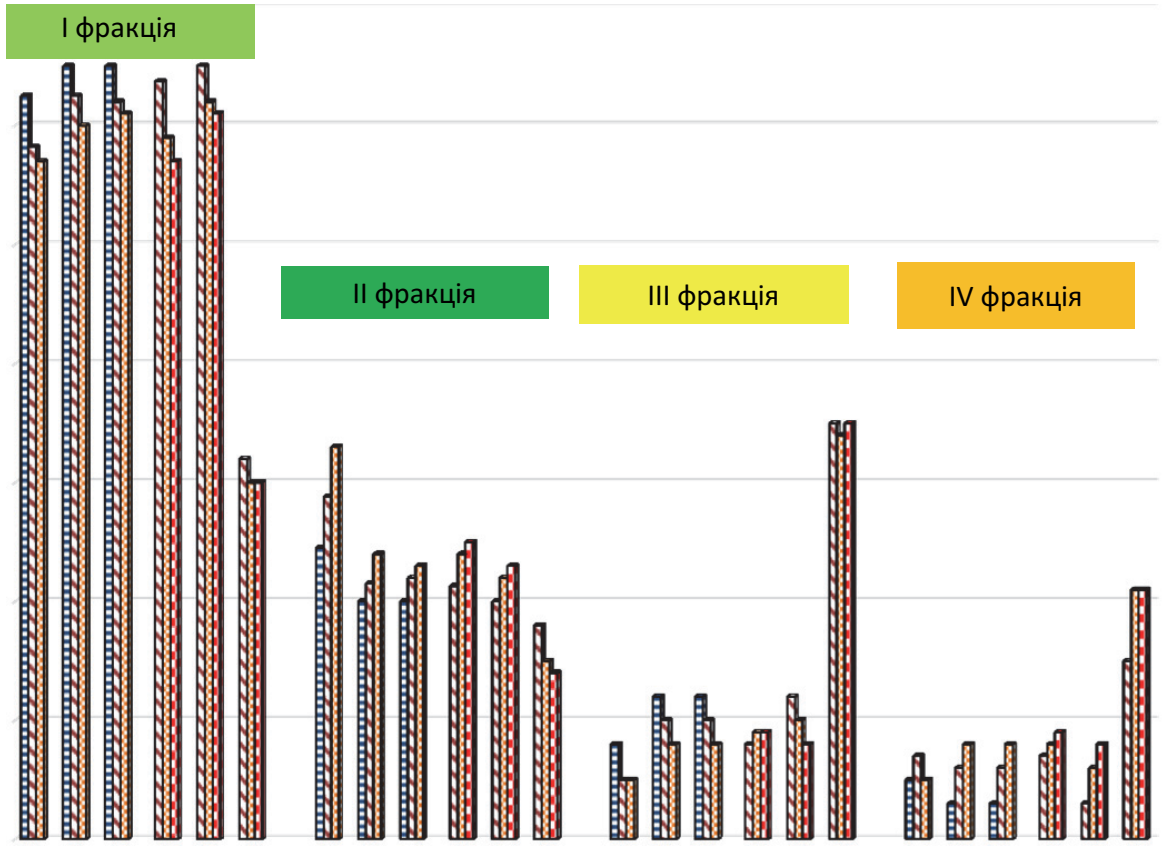

Рис. 3. Вихід насіння (\%) батьківських форм кукурудзи за фракціями залежно від густоти стояння рослин, (середнє за 2014 - 2018 рр.)

Зазначено (рис. 4., рис. 5.), що в рослин гібриду Ріст СВ найвищу масу 1000 насінин - 287,2 г, енергію проростання - 95,9\% та схожості - 98,6 \% сформу- вали за густоти 75 тис./га. За цієї ж густоти стояння рослин гібрид Рушник СВ сформував найвищий показник маси 1000 насінин - 326,2 г, енергії проро-

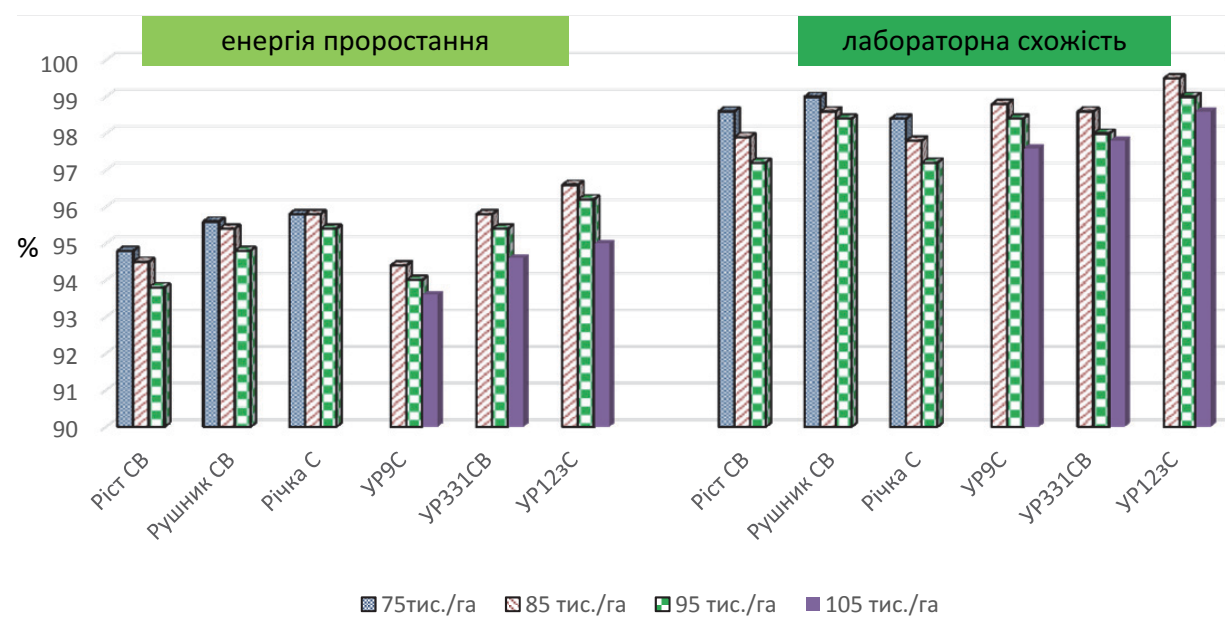

Рис. 4. Посівні якості насіння (\%) батьківських компонентів кукурудзи залежно від густоти стояння рослин, (середнє за 2014 - 2018 рр.) 


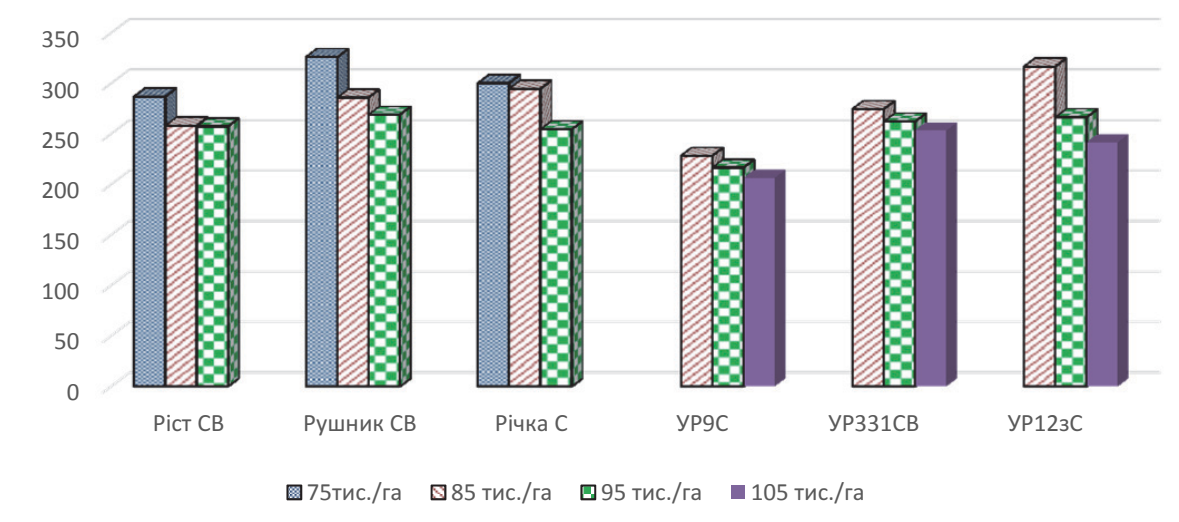

Рис. 5. Маса 1000 насінин (г.), батьківських компонентів кукурудзи залежно від густоти стояння рослин, (середнс за 2014 - 2018 рр.)

стання $-95,6 \%$ та схожості - 99,0 \%. Ця ж густота стояння була найсприятливішою для гібрида Річка С рослини якого сформували масу 1000 насінин - 300,5 г, енергією проростання та схожість $95,8 \%$ та $-98,4 \%$. Серед ліній УР 9 зС найвищу масу 1000 насінин - 228,5 г, 3 енергією проростання насіння - 94,4\% та схожості- $98,8 \%$ рослини сформували за густоти стояння 85 тис./га, а із загущенням до 95 тис./га спостерігалося зниження маси 1000 насінин - 206,7 г, енергії проростання та схожості відповідно до 93,6 \% та - 97,6\%.

\section{Висновки.}

За результатами досліджень встановлено, що найбільш оптимальною густотою стояння рослин для батьківських компонентів гібридів Ріст СВ та Рушник СВ виявилася 75 тис./га, за якої: гібрид Ріст $\mathrm{CB}$ забезпечив найбільший вихід (I - 62,5 \% і II - 24,5\%) фракції та високим показником посівних якостей: масою 1000 насінин 287,2 г, енергією проростання - 95,9 \% та схожістю - 98,6 \%; а гібрид Рушник CВ - найвищий вихід (I - 65,0 \% i II - 20 \%) фракції та високим показником посівних якостей: масою 1000 насінин - 326,2 г, енергісю проростання - 95,6\% та схожістю - 99,0\%. Для гібрида Річка С найбільш оптимальною виявилася 95 тис./га, що забезпечило найвищий вихід (I - 65 \% i II - 20 \%) фракції та високим показником посівних якостей: масою 1000 насінин $-254,7$ г., енергією проростання $-95,4 \%$ та схожістю - 97,2\%.

Оптимальною густотою стояння для ліній УР 9 зС та УР 12 зС виявилася 85 тис./га, а для УР $331 \mathrm{CB}$ 95 тис./га, що дозволило отримати вихід насіння найбільш цінних I та II фракцій та посівних якостей насіння: маса 1000 насінин, енергія проростання, схожість. Відповідно для УР $9{ }_{3} \mathrm{C}(63,7 \%, 21,3 \%, 228,5$ г, 94,4\%, $98,8 \%)$, УР 12 зС $(63,7 \%, 21,3 \%$, 316,9 г, 96,6\%, 99,5\%), УР $331 \mathrm{CB}$ $(61,0 \%, 23,0 \%, 266,6$ г, $96 \%, 99,0 \%)$.

Для отримання найбільш цінних фракцій насіння кукурудзи та високої посівної придатності вищевказані батьківські компоненти доцільно вирощувати за вказаною рекомендованою густотою стояння. Оптимальні густоти стояння досліджуваних батьківських компонентів створюють передумови керування формуванням продуктив- 
ності рослин та господарсько-цінних характеристик гібридів та ліній, а звідси - потенційно-можливою урожайністю фенотипів та рівнем біологічного та господарського урожаю насіння.

\section{References}

1. Krasnovskyi S. A., \& Zhemoida V. L.(2010). Selektsiia kukurudzy na stiikist do abiotychnykh faktoriv. Vseukrainska naukova konferentsiia molodykh uchenykh. 1, 185-186. [in Ukrainian]

2. Kalenska, S. M., \& Taran, V. Í. (2018). Harvest index of corn hybrids, depending on plant density, fertilizing doses and weather conditions of growing. Plant Varieties Studying and Protection, 14(4), 415-421. [in Ukrainian] https://doi. org/10.21498/2518-1017.14.4.2018.151909

3. Pankin V. S., \& Pavliuk O.O. (2005). Hustota stoiannia roslyn hibrydiv kukurudzy $v$ umovakh Tsentralnoho Lisostepu Ukrainy. Biuleten instytutu zernovoho hospodarstva. 23-24. 33-35. [in Ukrainian]

4. Allard R. W. (1996) Genetic basis of the evolution of adaptenelnesin plants. Euphitica, 1996. 92 (1-2), 1-11.

5. Khromyak V.M. (1986) Optimal'naya gustota stoyaniya rastenij. Kukuruza i sorgo. 1. 24. [in Russian]

6. Abelmasov, O. V., \& Bebekh, A. V. (2018) Specifics of the key yield components manifestation in self-pollinated corn lines under different growing conditions. Plant Varieties Studying and Protection, 14(2), 209-214. [in Ukrainian] https://doi.org/10.21498/25181017.14.2.2018.134771

7. Kemanian, A. R., Stöckle, C. O., Huggins, D. R., \& Viega, L. M. (2007). A simple method to estimate harvest index in grain crops.
Field Crop. Res., 103(3), 208-216. doi: 10.1016/ j.fcr.2007.06.007

8. Leshchuk, N. V., Tagantsova, M. M., \& Stadnichenko, O. A. (2013). Methodological aspects of the use of the histogram and the variation curve of morphological traits of maize (Zea mays L.) hybrids. Plant Var. Stud. Prot., 1, 43-46. [in Ukrainian] doi: 10.21498/2518-1017.1(18).2013.58712

9. Kapustin S. I., Kovtun M. V, Kapustin A. S. ta in. (2009) Vplyv strokiv sivby na urozhainist kukurudzy, strukturni pokaznyky roslyn ta yii vodospozhyvannia. Naukovyi visnyk Luhanskoho natsionalnoho ahrarnoho universytetu. Seriia: Silskohospodarski nauky. 11. 22-29. [in Ukrainian]

10. Teller E., Caldeira K., G.(1999) Canavan at. al. Long-range weather prediction and prevention of climate catastrophes:a status report. International Seminar on Planetary Emergencies. (Erice, Italy, 19-24 August).. P. 3-44.

11. Dospekhov B.A. (1989) Metodika polevogo opy ta s osnovami statisticheskoj obrabotki rezul tatov issledovanij. [in Russian]

12. Tkachyk, S. 0. (Ed.). (2016). Metodyka provedennia ekspertyzy sortiv roslyn hrupy zernovykh, krupianykh ta zernobobovykh na prydatnist do poshyrennia v Ukraini [Method for grain, cereal and leguminous varieties VCU expert examination in Ukraine]. Vinnytsia: Nilan-LTD. [in Ukrainian]

13. Tkachyk, S. 0. (Ed.). (2016). Metodyka provedennia ekspertyzy sortiv roslyn hrupy zernovykh na vidminnist, odnoridnist i stabilnist [Method of examination of plant varieties of the group of grains for difference, homogeneity and stability]. (2nd ed., rev.). Vinnytsia: Nilan-LTD. [in Ukrainian]

\footnotetext{
Bagatchenko V. V., Jemeida V. L., Spriazhka R. O. (2020). FORMATION OF FRACTIONAL COMPOSITION AND SOWING QUALITY OF SEEDS, PARENTAL COMPONENTS OF MAIZE DEPENDING ON DENSITY. PLANT AND SOIL SCIENCE, 11(1): 79-87. https://doi.org/10.31548/agr2020.01.079
} 
Abstract. Results of research of influence of standing density on the yield of fractional composition and sowing qualities of seeds of parent components of corn are presented (simple hybrids) Rist SV, Rushnyk SV, Richka S and (self-dusting lines) UR 9zS, UR 331 SV, UR 12 zS, which are parent components of hybrids of corn are listed in the State register of plant varieties of Ukraine.

It was established that the studied parental components ensured the formation of various fractions and sowing qualities of seeds depending on genetic characteristics and different plant densities, which made it possible to optimize the studied agrotechnical methods of growing them.

Optimum plant densities will increase the yield of seeds of the most valuable fractions of maize I and II and their sowing qualities (weight of 1000 seeds, germination energy, germination), respectively, for the parent components of Rist CB (62.5\%, 24.5\%, $287.2 \mathrm{~g}, 95.9 \%, 98.6 \%)$ and Rushnyk SV (65.0\%, 20.0\%, 326.2 g, 95.6\%, 99.0\%) is 75 thousand / ha, for Richka C $(65.0 \%$, $20.0 \%, 254.7 \mathrm{~g}, 95.4 \%, 97.2 \%)$ and UR $331 \mathrm{CB}(61.0 \%, 23.0 \%, 266.6 \mathrm{~g}, 96 \%), 99.0 \%) 95$ thousand / ha and for SD 9 zS (63.7\%, 21.3\%, 228.5 g, 94.4\%, 98.8\%) and SD 12 zS (63.7\%, 21.3\%, 316.9 g, 96.6\%, 99.5\%) 85 thousand / ha.

Key words: corn, parent components, self-filing lines, plant standing density, fractional composition, sowing validity 